Dariusz Jarosz

Institute of History, Polish Academy of Sciences, Warsaw, Poland

marpasztor@interia.pl

ORCID 0000-0002-7882-8532

\title{
Under Special Supervision. Creation and Beginnings of the Reading Rooms as a Problem in the Relations of the People's Republic of Poland with Austria, France, and Italy in 1945-1970
}

\begin{abstract}
The article aims at the presentation of the origins and beginnings of reading rooms: Italian, Austrian and French in the People's Republic of Poland until the end of the 60 s of the $20^{\text {th }}$ century, in a broader context of bilateral relations of Poland with France, Italy, and Austria. That enabled the determination of controversial issues restraining a process of establishing these units, as well as historical context influencing this process. The findings were based on archival source materials and a few research studies.
\end{abstract}

Key words: reading rooms - cultural institutes - Polish-Italian relations - Polish-French relations - Polish-Austrian relations.

„Z Badań nad Książką i Księgozbiorami Historycznymi” - Udział zagranicznych recenzentów w ocenie publikacji; Stworzenie anglojęzycznej wersji wydawniczej publikacji; Digitalizacja tomów archiwalnych rocznika w celu zapewnienia otwartego dostępu do nich przez Internet oraz wdrożenie i utrzymanie cyfrowej platformy redakcyjnej - zadanie finansowane w ramach umowy nr 653/P-DUN/2019 ze środków Ministra Nauki i Szkolnictwa Wyższego przeznaczonych na działalność upowszechniającą naukę. 
Books, reading rooms and libraries

Projects concerning international relations can hardly be found among current Polish research on political book studies. The historians explore these topics rarely, not very familiar with a field "taken over" by the book researchers. The latter are afraid about adequate competencies in political history. Meanwhile, as the modern history of Poland reveals, the establishment of libraries and reading rooms was entangled in complicated interstate relations. The aim of this study is to present political context influencing attempts of establishing Austrian, French and Italian reading rooms in the People's Republic of Poland (PRP).

Chronologically, the study goes back to the years just after World War II, when foundations of new international relations were being developed, and ends at the end of the 60ties. Then these reading rooms were established, thanks to warmed relations between the East and the West.

\section{General context}

In the discussed period international relations were defined by the "cold war" paradigm. However, until 1948-1949 bilateral relations of Poland with the West were quite friendly and fruitful. Trade exchange was established, foundations of cultural cooperation developed, even a closer political cooperation was discussed (vide concepts of a renew of Polish-French political alliance in the years 1946-19471). These relations worsened already in 1947, because the states of the Eastern Bloc rejected the Marshall Plan, and established the Kominform. Mutual hostility, resulting in significant cooling of these relations, influenced also cultural contacts, which - instead of strengthening - became increasingly rare, and even hostile.

This situation had changed slowly due to political thaw, originated by the death of Stalin on March 5, 1953. Symptoms of this thaw had strengthened slowly, although periods of acute "frosts" were not lacking (Soviet invasion in Hungary, and attempted invasion in Poland in 1956, the Berlin crisis in 1961). Investing in cultural relations faced resistance, arising from the burden of "baggage of the past", especially that of the Stalinist period. It is confirmed even by problems with the establishment (revival) of Italian, French and Austrian cultural institutions in Poland.

1 M. Pasztor, Francuska polityka "budowania mostów" w dzielacej się Europie - przykład Polski i Czechosłowacji (1944-1947), "Studia z Dziejów Rosji i Europy Środkowo-Wschodniej" 2002, vol. 37, pp. 117-131. 
Instead of institutes: reading rooms in the light of bilateral relations

\section{The Italian case}

Italian efforts towards revival of cultural institutions active in Poland before the war, i.e. the Italian Cultural Institute (Istituto Italiano di Cultura), and the Dante Alighieri Society started just in 1945. Both institutions inaugurated their activities in Cracow in December that year, however, they froze soon ${ }^{2}$.

The discussion on this topic resumed at the turnover of the $50 \mathrm{~s}$ and $60 \mathrm{~s}^{3}$. The normalization of cultural relations enabled the establishment and activity of the Polish-Italian Mixed Commission, as a body responsible for developing programs of cultural and scientific cooperation. The program for the period March 1, 1962 - June 30, 1963, expressed a will of cooperation and support for dissemination of information science, exchange, and translation of books. It also listed settlements concerning an exchange of exhibitions, the participation of Italian publishers in the International Book Fair in Warsaw, the cooperation of libraries and archives, broadcasting and television. It also stated the necessity of cooperation concerning the development of dictionaries: Italian-Polish and Polish-Italian, as well as textbooks for teaching these two languages ${ }^{4}$.

A Polish-Italian cultural convention, signed on March 25, 1965, proved increased activities in this range, although the Italian party hindered its ratification. It was modelled after a similar agreement signed with the USSR in Moscow on February 9, $1960^{5}$.

According to the agreement of 1965, Poland and Italy were obliged to any mutual help in regard to scientific and cultural cooperation. However, the most important is article 2, including an agreement for establishment in Warsaw by the Italian government the Reading Room, aiming at the development of the scientific and cultural activity. In return, the Italian party agreed for further

2 Niech żyje Polska! Niech żyje Italia! Manifestacja przyjaźni polsko-włoskiej w murach Krakowa, "Dziennik Polski" 1945, no. 302; Archiwum Ministerstwa Spraw Zagranicznych w Warszawie [Archive of the Ministry for Foreign Affairs in Warsaw] (hereinafter: AMSZ), no. 6, vol. 1215, v. 80, Prof. J. Dąbrowski, Dean of the Faculty of Humanities, Jagiellonian University to the MFA in Warsaw, Kraków, 19 XI 1945.

3 See more: D. Jarosz, M. Pasztor, “Odwilż” w polsko-włoskich stosunkach kulturalnych i naukowych w latach 1955 -1958, "Analecta. Studia i Materiały z Dziejów Nauki” 2012, no. 1-2, pp. 339-352.

4 D. Jarosz, Kultura i nauka w relacjach między Polska Rzeczpospolita Ludowa a Republikq Wtoska w latach 1959-1970, “Analecta. Studia i Materiały z Dziejów Nauki” 2018, no. 1, p. 43.

5 M. Pasztor, D. Jarosz, Nie tylko Fiat. Z dziejów stosunków polsko-włoskich 1945-1989, Warszawa 2018, p. 362. 
maintenance of the Research Station in Rome by the Polish Academy of Science, of similar range.

Both parties pledged to support the exchange of scientific, cultural and educational books and publications, translation of scientific, literary and artistic works, organization of cultural, artistic and scientific exhibitions. The agreement was concluded for five years, after which it was automatically extended for the next five-year periods if neither party terminated it ${ }^{6}$.

In the same year, the Italian Reading Room was open in Warsaw. As found in Italian diplomatic records, it required many organizational efforts and tempering "oversensitiveness" of the French embassy in Warsaw, envious of a leading role in cultural relations with Poland. The Italians were officially informed about the PRP authorities' acceptance for opening the Reading Room (together with a Library) in spring 1964. At that time the search for suitable premises began, and then their renovation. The new cultural institution consisted of a reading room, a library, a conference (and cinema) theatre, a room for Italian courses, and an office. The library amounted to more than 5.000 volumes. On the occasion of its opening exhibitions were organized, of Italian books in Poznań, Cracow, and Warsaw (April - May 1965), of manuscripts and incunabula of Dante, from Polish library collections?

The activity of this institution had expanded gradually. In 1971 the library collection amounted to approx.. 6.000 volumes (with approx.. 1500 readers), collections of music and film records also enlarged. 15 courses of Italian were realized for 716 participants. A special course for the workers of the Fiat factory in Poland was organized. The unit cooperated vividly with the Society of Polish-Italian Friendship ${ }^{8}$.

\section{The French case}

In contrast to Italy, cultural relations between Paris and France at that time were much more stormy. Just after the war, Paris paid special attention to the maintenance of French cultural and civilizational influences in Poland, as a counterbalance to an Anglo-Saxon world, perceived as a hostile by Moscow and Warsaw9.

6 Umowa kulturalna między Rządem Polskiej Rzeczypospolitej Ludowej a Rządem Republiki Włoskiej sporządzona w Warszawie dnia 25 marca 1965 r., Dz. U. [Official Journal] 1969, no. 15, pos. 104.

7 Archivio Centrale dello Stato - Roma (hereinafter: ACS), A. Moro set, busta 81, L'Ambasciata d'Italia a Varsavia, Visita di Saragat a Varsavia, Influeze della culura italiana in Polonia, 14 X 1965 , unnumbered page.

8 ACS, A. Moro set, busta 136, Ministero degli Affari Esteriu. Segreteria Generale. Visita a Roma dell viceministro degli Affari Esteri Polacco Adam Willman, 9-10 XI 1971, unnumbered page.

9 M. Pasztor, D. Jarosz, Działalność Instytutu Francuskiego w Polsce w latach 1925-1989. Czesść 
A mission of French professors, sent by the Directorate General for Cultural Relations in the French Ministry for Foreign Affairs (MFA), visited Warsaw on September 24, 1945, to establish scientific and cultural contacts and to orient in Polish needs in that field. It was chaired by André Choley, a geographer, professor of the Sorbonne University, dean of the Faculty of Literature. French guests were kindly welcomed by Polish authorities and academics.

What were the results of this visit? First of all, the guests postulated to reopen the French Institute in Poland as soon as possible, with branches in Cracow, Poznań, Wrocław, and Łódź. They advised the renovation of its library, partially destroyed and dispersed during the war. Significant deficiencies in the scientific literature were found. Poland - as wrote Prof. Cholley in his report after the mission - needs a lot of technical books and manuals, which should be translated into Polish. However, this appeal had not received positive reactions among French publishers ${ }^{10}$.

The French MFA drew some conclusions from the opinions of the mission participants. One of its effects was the enhancement of the provision of indispensable French publications. If in the year 1945 adequate units of this ministry send to Poland $1400 \mathrm{~kg}$ of books and scientific reviews, costing 200 thousand francs, in $1946-7$ thousand $\mathrm{kg}$ costing 2.500 thousand francs ${ }^{11}$.

At the same time, Warsaw authorities referred favourably to plans of reopening the French Institute in Poland and supported the maintenance of the French language as obligatory in Polish education ${ }^{12}$.

Adequate statements concerning this topic can be found in the Polish-French convention of intellectual cooperation, signed on February 19, 1947, in Paris ${ }^{13}$. It included - among others - a commitment to support the translation of literary and scientific works, as well as to facilitate relations and cooperation between "representatives of science, literature, the arts, theatre, music, film, and broadcasting". The parties were obliged to support also mutual exchange of books and journals, daily newspapers and other publications, organization of art exhibitions, theatre plays and "artistically valuable" films (art. 2 and 3).

druga: lata 1945-1989, "Polski Przegląd Dyplomatyczny" 2008, no. 3, p. 121; idem, Robineau, Bassaler i inni. Z dziejów stosunków polsko-francuskich w latach 1948-1953, Torun 2001, pp. 52-53.

10 Archives du Ministère des Affaires Étrangères (hereinafter: AMAE), Direction Générale des Relations Culturelles, Scientifiques et Techniques, Enseignement 1945-1961, Pologne 1945-1947, vol. 77, Le Ministre des Affaires Étrangeres à M. le Recteur de l'Universisté de Paris , 6 oct. 1945.

11 AMAE, Direction Générale des Relations Culturelles, Scientifiques et Techniques, Oeuvres Diverses - Échanges Culturels 1945-1959, Pologne, vol. 46, Note pour la Cabinet du Ministre (en réponse à une question écrite sur la diffusion de la press et de la littérature française en Europe centrale et, notamment, en Pologne) 20 mai [1947].

12 AMSZ, no. 6, vol. 986, v. 69, Conversation of minister Modzelewski with ambassador Garreau Wwa, 2 X 1945, p. 24.

13 The convention text - see: Dz. U. [Official Journal] no. 62, pos. 363. 
The postulated Polish-French Mixed Commission was planned to supervise the realization of these goals. It was obliged to develop an offer of bilateral agreement concerning reopening of the French Institute in Warsaw, Kraków, and Poznan, "with its potential branches", and functioning of the Polish Library and Research Station in Paris, belonging to the Polish Academy of Arts and Sciences (PAL), "with its potential branches" as well (art. 7a).

Regardless of goodwill, the establishment of the Institute was an undertaking organisationally complicated. Former headquarters of the Institute in the Staszic Palace in the capital of Poland was devastated, and the library dispersed ${ }^{14}$.

Therefore the Institute in Cracow was opened first (on May 27, 1946, in the Lubomirski Palace) ${ }^{15}$. However, the official opening of this Institute in both cities (in Warsaw in temporary premise - at Aleje Jerozolimskie 32), participated by Louis Joxe, chair of the Directorate General for Cultural Relations in MFA, took place in June $1947^{16}$, and in Gdańsk on October 22, 1947. Its branches were also opened in Szczecin, Lublin, Łódź, Poznań, Gliwice, and Katowice (a library). The Institute activity focused on French language courses ${ }^{17}$.

The Institute worked quite well until an apogee of Stalinism when an increasing tension in Polish-French relationships influenced its further activities. The French party arrested Polish miners participating in strikes in the mines in northern France. Part of them were expulsed. French authorities proceeded also with the liquidation of Polish education, sponsored by the Polish Embassy in Paris.

In these circumstances, Polish authorities decided to apply retaliatory measures to the French teaching in Poland. It was pronounced by the Polish ambassador Jerzy Putrament just on December 10, during his visit to the French MFA. Expected hit took place on December 13, 1949, when Warsaw authorities, in the face of arrest and deportation of Polish inspectors and teachers in France, demanded 11 professors of the Institute to leave Poland. Adequate note was presented to the Embassy of France the same day ${ }^{18}$.

In the apogee of Stalinism, the problem of the Institute renewal had been mentioned ritually in French diplomats' addresses, who perceived its suspension as breaking the cultural convention mentioned above.

14 AMAE, Direction de la Direction Générale des Relations Culturelles, Scientifiques et Techniques, Enseignement 1945-1961, Pologne 1945-1947, vol. 77, M. R. Garreau ambassadeur en Pologne à G. Bidault, Varsovie 26 nov. 1946.

15 Otwarcie Instytutu Francuskiego w Krakowie, "Rzeczpospolita" 1946, no. 147; Instytut Francuski - tacznikiem kulturalnym, "Echo Krakowa" 1946, no. 79.

16 Otwarcie Instytutu Francuskiego w Warszawie, "Rzeczpospolita" 1947, no. 162; W pracy nad zbliżeniem kulturalnym polsko-francuskim, "Rzeczpospolita" 1947, no. 163.

17 M. Pasztor, D. Jarosz, Działalność Instytutu..., pp. 125-126.

18 D. Jarosz, M. Pasztor, Robienau, Bassaler..., pp. 180-183. 
As time passed, and the political climate of Warsaw and Paris relations had improved, reactivation of the Institute had been discussed more and more often. The 10 years period of the cultural convention binding was over in 1957, which opened the question of signing a new one or developing another document. The French tended to replace the convention with a joint declaration of both governments, postponing negotiations concerning the former to a later date. Among others, an issue of renewed exchange of scientific books and publications was discussed, as well as teaching French language in Poland ${ }^{19}$.

Analysis of diplomatic talks of that time reveals that cultural topic was an important issue. According to the practice verified just after the war, the French decided to send a mission to Poland, to orient themselves in a situation.

Its participants, headed by Jean Bourilly, visited Warsaw, Cracow, and Poznań at the turnover of January and February 1957. They met representatives of the Polish culture and academic circles, as well as politics (among others: Stefan Żółkiewski, minister for higher education, Władysław Bieńkowski, minister for education, Prof. Stanisław Turski, Rector of the University of Warsaw, and professors Tadeusz Kotarbiński, Mieczysław Brahmer, Aleksander Gieysztor, Wacław Sierpiński, as well as Maria Dąbrowska, Julian Przyboś, Erwin Axer, Jerzy Turowicz and Jacek Woźniakowski. The following areas were identified in the final report as requiring immediate cultural actions: scholarships for young researchers, filling deficiencies in books, scientific reviews, and journals. The topic of publication exchange was to be one of the most important functions of the French Institute, which had to be reopened ${ }^{20}$.

The most important effect of these meetings and reconciliation of positions was the Polish-French declaration on cultural cooperation, accepted on July 9, 1957. It was the result of compromise. Warsaw made bigger concessions. As stated in the introduction: "The Polish Government and the French Government - willing to find means which would contribute to a general improvement of mutual relations in all fields - believe that cultural relations are a particularly grateful field for manifesting a mutual goodwill". To reach this goal, both parties decided to continue efforts "aiming at development, with mutual agreement, bilateral cultural relations, mediated by adequate official institutions" (point 1). It was decided (point 2) to deepen mutual understanding between both nations with "any adequate means, in particular through"

19 AMSZ, no. 8, vol. 697, v. 52, M. Żuławski (cultural counsellor) note from the conversation of Gajewski and minister Daridan, July 13, 1956, p. 65.

20 AMAE, Direction de la Direction Générale des Relations Culturelles, Scientifiques et Techniques, Enseignement 1945-1961, vol. 298, Jean Bourrilly, Chargé de Mission Culturelle à M. le Directeur Général des Affaires Culturelles et Techniques, s/c de PP.E. Monsieur l'Ambassadeur de France à Varsovie, 20 février 1957, unnumbered page. 
a. free movement of people between both countries. Both governments express their satisfaction with hitherto results in this field;

b. mutual exchange and dissemination in both countries books, newspapers, and journals - literary, artistic, scientific or technological.

Polish negotiators tried to eliminate (unsuccessfully) the statement from point $2 \mathrm{a}$ of the declaration. However, the most controversial was point 3. Finally, it stated that the governments decide to "support knowledge and usage of the French language in Poland, and the Polish language in France:

a. through the development of teaching French in Polish secondary and higher education, and teaching Polish in French schools respectively. Often exchange of views between both parties should enable mutual agreement in matters of great importance, namely teaching of the Polish language, which children of Polish origin attending primary schools are entitled to in France;

b. through the support of establishing departments and lectures of the French language and literature in Poland, as well as the Polish language and literature in France, and through an acceleration of reopening or establishing institutes of research units - Polish in France, and French in Poland".

Point 3a, as presented by the Polish party, included the statement concerning provision, "of teaching Polish language, literature, history and geography of children of the Polish origin living in France, in cooperation between competent Polish and French authorities". It was much more obliging for the French authorities, therefore it was rejected. Polish negotiators wanted also to incorporate a clear notice concerning support for opening the French Institute into the declaration, and acceptance of Warsaw authorities' supervision on the Polish Library in Paris, what was rejected as well, according to their anticipations. In the further part of this document, the authorities pledged (point 4) "to enable citizens of both states getting to know the culture and achievements of the other party" ${ }^{21}$.

It is clear that cultural relations had been developing better that time, however difficult problems existed, the significance of which entered directly political relations on the highest level. They could not be solved even by the Mixed

${ }^{21}$ AMSZ, no. 8, vol. 824, v. 60, Winiewicz to Cyrankiewicz, Warszawa, July 8, 1957, unnumbered page; ibidem, Propozycje zmian do projektu deklaracji przesłane jako instrukcja Dyrektora Departamentu II H. Bireckiego dla ambasadora Gajewskiego z 28 maja 1957, unnumbered page. On the role of the dispute on an ownership of the Polish Library in Paris for negotiations concerning reopening of the French Institute in Poland - see: D. Jarosz, M. Pasztor, Rola sporu o Bibliotekę Polskg w Paryżu w stosunkach polsko-francuskich w latach 1945-1980, "Z Badań nad Książką i Księgozbiorami Historycznymi", 2006, vol. 1, 2006, pp. 31-47. 
Commission, working more and more better. Such a problem was reactivation of the French Institute, of which a library and a reading room would be the most important structural elements.

As time passed the French party raised this issue more and more intensively. The problem was, that Warsaw put iunctim between opening the Institute and positive (for People's Republic of Poland) regulation of the status of the Polish Library in Paris ${ }^{22}$.

In new political circumstances after 1956, a compromise was searched. The needs of great politics contributed to finding adequate formula also in this case. The politics of opening for the East, promoted by gen. Charles de Gaulle, president of France, assumed the development of Paris' interests area in East Europe. Although this politics did not succeed, due to intensive pro-Moscow attitudes of eastern states, activities aimed at strengthening of French culture in this region began to bring first results. Just in time of preparations for the visit of French Prime Minister Maurice Couve de Murville in Poland in December 1965, the French party demanded establishment in Warsaw and several other Polish cities - "permanent French cultural institutions". The French specifically esteemed opening the French reading room in Warsaw (like those Italian and Austrian), and they did not see any possibility of signing negotiated agreements concerning cultural and scientific cooperation without it. As a result of these pressures the Polish authorities agreed to open the French Reading Room in Cracow (adequate statement was put in the program of cultural cooperation of December 1965), and the analogous one in Warsaw. The decision for the latter was confirmed by the PRP Embassy to the French authorities in March 1966. It was also for Paris a condition to resign from the idea of reopening the French Institute in Poland. During his visit to Poland in May 1966 the chief of French diplomacy signed these agreements and opened the Reading Room in $\mathrm{Cracow}^{23}$. It was located in the Lubomirski Palace. Its library amounted to approx.. 6.000 volumes in 1967 and had been developing. The Reading Room offered also an audiovisual laboratory, visited that time by approx. 250 students, because local conditions allow for only that many ${ }^{24}$.

Decision on opening the Reading Room in Warsaw was formally made during gen. de Gaulle's visit to Poland (September 6-12,1967). Its inauguration took place a bit later, in 1968, in a small place consisting of two rooms

\footnotetext{
22 D. Jarosz, M. Pasztor, Rola sporu o Bibliotekę Polska ..., pp. 31-35.

23 See: Umowa kulturalna między Rzadem Polskiej Rzeczypospolitej Ludowej a Rzadem Republiki Francuskiej podpisana 20 maja 1966 r., [in:] Zbiór umów międzynarodowych Polskiej Rzeczypospolitej Ludowej 1966, Warszawa 1971, pp. 70-75; Umowa o wspótpracy naukowej i technicznej między Rządem Polskiej Rzeczypospolitej Ludowej a Rządem Republiki Francuskiej, ibidem, pp. 7981.

24 M. Pasztor, D. Jarosz, Działalność Instytutu ..., p. 137.
} 
and a library. The increase of this place (at Świętokrzyska 36 str.) took place in 1970 and enabled "spreading the wings" by this institution. A library, along with music and film lending, teaching and cultural manifestations, was the most important form of the Reading Room activity ${ }^{25}$. By that means French reading rooms - substitutes of the French Institute - had received an opportunity to act. Soon after reconstruction of the French Institute took place.

\section{The Austrian case}

Establishment of the Austrian Reading Room in Warsaw was the undertaking - as in French and Italian cases - possible for realization in an atmosphere of weakened tension in international relations after 1956. Receiving the status of a neutral state (May 15, 1955) was an additional factor. It opened a possibility to activate relations with Poland. A visit by Bruno Kreisky, an Austrian minister for foreign affairs in Poland on March 1-3, 1960 was an important event in these relations. The Organisational Committee of the Polish-Austrian society was established in December $1959^{26}$.

As in other cases, decisions of the establishment of the Reading Room were made at the highest level of authority.

Stefan Verosta, deputy of the Austrian Republic in Poland, supported opening an Austrian cultural center in Warsaw. It is him who presented such an initiative just in July 1958, during a meeting with the Polish minister for foreign affairs Adam Rapacki. Verosta tried also to discover the viewpoint of the $1^{\text {st }}$ secretary of the PRP legacy in Wien in this matter. The deputy stated in talks, that the Austrian party was aware of local difficulties in Warsaw, and declared a will to pay any costs related to finding adequate premise. Management of Department IV of the Polish MFA found this initiative interesting in August 1958, but on a reciprocal basis, i.e. opening a similar Polish reading room in Wien. It stated also that "attractiveness of the Austrian reading room in Poland would be higher than a potential Polish one in Austria [...] An Austrian reading room [...] in Warsaw, as another next to the GDR's one German-language institution, certainly would enjoy permanent attendance". Moreover, regarding that it would require "huge financial effort", the Department IV proposed "to postpone an answer for Verosta, and in further evidence of permanent Austrian interest for an Austrian reading room in Warsaw, to agree for its establishment, reserving

\footnotetext{
25 Ibidem, p. 137.

26 P.P. Syndoman, Polsko-austriackie stosunki dyplomatyczne $i$ kontakty polityczne $w$ latach 1970-1989, [in:] Austria i relacje polsko-austriackie w XX i XXI wieku. Polityka-kultura-gospodarka, ed. by A. Kisztelińska-Węgrzyńska and K. A. Kuczyński, Łódź 2014, pp. 104-105; J. Tebinka, Dyplomacja popaździernikowa, [in:] Historia dyplomacji polskiej, vol. 6: 1944/1945-1989, ed. by W. Materski and W. Michowicz, Warszawa 2010, pp. 551-552.
} 
on the basis of reciprocity the right to create a similar institution in Vienna. We would exercise this right depending on the needs and funds. If the Austrian Legacy, receiving our consent to open a reading room, would ask us for organizational help, we should help them in finding adequate premises under the following conditions: possible interior finish, equipment, or adaptation would be at the expense of the Austrian party"27.

Exploratory talks still had lasted. The parties agreed, and on September 27, 1958 , the consent for establishment of such an institution in Warsaw, on a reciprocal basis, was given. It was confirmed during minister Kreisky visit to Poland. Official opening of the Polish Reading Room in Wien took place during minister A. Rapacki visit in Austria, in March 1961. As regards opening the institution in Warsaw, finding adequate premises was troublesome. The Austrian Embassy in Warsaw informed in the note of August 3, 1961 that it was going to open the reading room when receiving a room at Willowa 2 street, in the building reconstructed in the years 1946-1948 by five co-owners, with financial support of the Austrian government. The Embassy Secretary had been living there since 1958, in the apartment on the fourth floor. The Austrians were going to purchase the whole building, but they needed approval of adequate Polish authorities ${ }^{28}$. Due to difficulties related to this situation, including the inability of getting a loan in PLN (the Polish party insisted that purchase can be realized only for foreign currency), the Austrians resigned from this premises. The Embassy referred officially to the Polish MFA in November 1961, asking for help in this matter. Finally, the Presidium of the National Council of the city of Warsaw indicated space at Zielna street at the corner of Próżna for the needs of the Reading Room, and the Ministry of Finance in January 1963 accepted payment for adaptation in PLN, in contrary to the premise at Willowa street ${ }^{29}$. The Austrian Reading Room began its activity in Warsaw in March $1965^{30}$.

Just like in the case of Italian and French institutions described above, this activity exceeded significantly tasks of "an ordinary reading room" - at least as for standards of that time. In the descriptions of this activity until 1969 prepared by the Polish Ministry of the Interior (MI) it is obviously mentioned, that the Reading Room offers a wide range of current Austrian newspapers and

27 AMSZ, no. 17, vol. 37, v. 4, Departament IV MSZ do tow. min, M. Naszkowskiego, Warszawa, 26 VI 1958, pp. 50-51.

28 Ibidem, Ambasada Austriacka w Polsce do Ministerstwa Spraw Zagranicznych PRL, Warszawa, 3 VIII 1961, pp 67-68; ibidem, Tajna notatka dotycząca otwarcia czytelni austriackiej w Warszawie [1963], pp. 75-76.

29 Ibidem, Tajna notatka dotycząca otwarcia..., pp. 75-76.

30 Archiwum Instytutu Pamięci Narodowej [Archive of the Institute of National Remembrance, hereinafter: AIPN], BU 003273/279, vol. 3, Kontrwywiadowcza charakterystyka działalności Czytelni Austriackiej w Warszawie, ul. Próżna 8, Warszawa, 7 VII 1969, p. 7; ibidem, Informacja, Warszawa, 25 X 1963, p. 30. 
that the library is open on a daily basis, collecting publications mostly in humanities. Besides, the Austrian institution often organized lectures concerning modern Austria, its culture and politics, concerts of Austrian musicians, presentations of Austrian documentary films, meetings with Austrian and Polish writers, artistic and architectural exhibitions, presentations of the objects of art from the museums.

These events were attended by several dozen to several hundred people. It was permanently visited by students and lecturers from German studies at the University of Warsaw. The Reading Room was most active just after its opening, in the years 1966-1967. Weakening of its activity had started at the beginning of 1968, due to a decreased budget. Until July 1967 the Reading Room was supervised only by the Austrian Ministry of Education, which did not skimp on funds for foreign propaganda. Supervision of the MFA meant huge savings, which influenced negatively program of activities.

All in all, this activity of the Reading Room in that time was due to its director Fritz Cocron Ph.D., former chief of the Austrian Cultural Institute in Paris, a slavist by profession, and admirer of Slavdom ${ }^{31}$.

Positive evaluation of adequate state units is proved by records in the bilateral agreement on cultural and scientific cooperation of December 20, 1967. It stated (among others) that the parties "express satisfaction from the activity of the Polish Reading Room in Wien, and the Austrian Reading Room in Warsaw, and they will support their further works" 32 .

The Reading Room had been organizing the more and more popular courses of German language (for the beginners, advanced, and so-called conversations) since 1969. Just in 1970 five of them were organized for 125 participants $^{33}$. Moreover, it realized a cultural activity in the university communities of Warsaw, Łódź, Cracow, Lublin, and Białystok. Two employees from Austria and four Polish were working there in 1968. On the contrary, the Polish Reading Room in Wien, located on a side street, sharing a premise with the "Strzecha" Association of Poles in Austria, was much less active ${ }^{34}$.

\footnotetext{
31 AIPN, BU 003273/279, vol. 3, Kontrwywiadowcza charakterystyka działalności Czytelni Austriackiej w Warszawie, ul. Próżna 8, Warszawa, 7 lipca 1969, p. 7-9.

32 Porozumienie o współpracy kulturalnej i naukowej między Rządem Polskiej Rzeczypospolitej Ludowej a Rządem Austrii z 10. XII 1967 r., [in:] A. Kisztelińska-Węgrzyńska, Traktaty polsko-austriackie z lat 1955-1989. Wybór umów dwustronnych, Łódź 2011, p. 77.

33 AIPN, BU 003273/279, vol. 3, notatka dotycząca działalności kulturalno-oświatowej prowadzonej przez Czytelnię Austriacką w Warszawie przy ul. Próżnej 8, Warszawa 2 sierpnia 1972, p. 11.

34 AMSZ, no. 17, vol. 37, v. 4, Notatka dla Tow. ministra A. Kruczkowskiego w sprawie proponowanej wymiany not dotyczącej Czytelni Polskiej w Wiedniu i Czytelni Austriackiej w Warszawie, 1, pp. 80-81.
} 
Reading rooms under special supervision

Reading rooms of western countries in Poland, opened in the 60s., were allowed to act, however under special surveillance of the Polish security service. Nothing has been found concerning the Italian Reading Room, however, documents from that time of the Polish Ministry of the Interior concerning the French one, although only a few, are quite meaningful.

They state that just in 1966 the new French cultural institution was invigilated, as proved by the so-called object folder "Obcy-I" (Foreigner-I), which had been completed until 1990.

As the "counterintelligence description" of the Institute states, its main goal was to promote achievements of French culture by film presentations, theatre plays, promotion of literature, French language courses, library and broad access to French newspapers for the Polish citizens, scientific conferences attended by Polish and French representatives of science and the arts ${ }^{35}$. The evidence proves that the Polish security services' interests were focused on the Reading Room staff, with its director of that time Jean-Paul Couchoud at the very center at the turnover of the $60 \mathrm{~s}$. and $70 \mathrm{~s}$. However, despite the efforts ("a figurehead of the case of operational verification, nickname Peszt" was invigilated, as said in the language of security services of that time), confirmation of his activity of any kind in intelligence had not been proved ${ }^{36}$.

The Austrian Reading Room staff was invigilated, too. Just in February 1969, the Polish MI started the object file codename "Dukat". The object was the Austrian Reading Room in Warsaw. The reason for starting this file was as follows: "The staff of this institution maintains broad relationships with the Polish citizens, therefore they are enabled to reach much essential information on political, economic and military situation in our country". The goal of such activity was defined as counteracting "hostile activity of capitalist cultural institution" ${ }^{37}$. In practice, the so-called penetration of the Reading Room space, as well as an apartment of its director turned out to be very difficult, because, as written in the MI document, "an iron safe type «Wertheim» in the director's apartment is beyond our technical capabilities" ${ }^{\prime 38}$. The Polish MI closely followed Cocron's actions, his contacts with representatives of

\footnotetext{
35 AIPN BU 0999/305, Object file "Obcy-I” 1966-1990, Charakterystyka kontrwywiadowcza oraz kierunkowy plan działań operacyjnych w sprawie obiektowej kryptonim "Obcy-I" no. 5063, Warszawa 5 IV 1978, p. 11.

36 Ibidem, Analiza operacyjnego sprawdzenia krypt. Peszt dot. dyrektora Czytelni francuskiej w Warszawie, Couchouda Jeana-Paula, Warszawa 19 VI 1972, p. 44.

37 AIPN, BU 003273/279, vol. 3, Wniosek o założenie teczki obiektowej, Warszawa, luty 1969, p. 4.

38 AIPN, BU 003273/279, vol. 3, Kontrwywiadowcza charakterystyka działalności Czytelni Austriackiej w Warszawie, ul. Próżna 8, Warszawa, 7 VII 1969, p. 10.
} 
intellectual opposition, including the poet Zbigniew Herbert (who reportedly conducted behind-the-scenes negotiations that led to awarding him the Herder Institute prize). Cocron were to be permanently informed about March 1968 events by them.

It is possible that the invigilation of the Reading Room and its staff was much broader, which can be revealed in further studies. However, even that what already has been established indicates that they were under special supervision of relevant structures of the Polish Ministry of the Interior, as a potential seedbed of "a hostile activity" in the cultural field. Further history of these cultural institutions seems to indicate that these fears were justified.

\section{Conclusions}

1. Establishment of the Reading Rooms in the 60 s. of the $20^{\text {th }}$ century was possible thanks to partial opening and political thaw in relationships between the PRP and France, Italy and Austria.

2. The Reading Rooms were perceived as a substitute for cultural institutes, difficult to establish at that time.

3. In each of these cases opening new cultural units required tedious discussions and agreements, searching for a compromise and omitting difficult issues.

4. The Reading Rooms activity was much broader than suggested by a name. Despite lending and bringing to Poland books and journals, they offered language courses, film presentations, and organized cultural events.

5. The Reading Rooms activity was monitored by the Polish security services, and their personnel (management in particular) was invigilated in regard to potential intelligence activity.

Translated by Matgorzata Kisilowska

\section{References}

Archival sources

Archiwum Instytutu Pamięci Narodowej w Warszawie, [Archive of the Institute of National Remembrance in Warsaw] BU 003273/279, vol. 3; BU 0999/305.

Archiwum Ministerstwa Spraw Zagranicznych w Warszawie [Archive of the Ministry for Foreign Affairs in Warsaw] no. 6,vol. 1215, v. 80; no. 6 , vol. 986, v. 69; no. 8, vol. 697 , v. 52 ; no. 8 , vol. 824 , v. 60 ; no. 17 , vol. 37 , v. 4 . 
Archives du Ministère des Affaires Étrangères Paris, Direction Générale des Relations Culturelles, Scientifiques et Techniques, Enseignement 1945-1961, Pologne 19451947, vol. 77, 298; Direction Générale des Relations Culturelles, Scientifiques et Techniques, Oeuvres Diverses - Échanges Culturels 1945-1959, Pologne, vol. 46.

Archivio Centrale dello Stato - Roma, A. Moro set, busta 81, 136.

Research studies, publications

Jarosz D., Kultura i nauka w relacjach między Polska Rzeczpospolita Ludowa a Republika Włoska w latach 1959-1970, “Analecta. Studia i Materiały z Dziejów Nauki” 2018, no. 1, pp. 41-68.

Jarosz D., Pasztor M., “Odwilż” w polsko-włoskich stosunkach kulturalnych i naukowych w latach 1955-1958, “Analecta. Studia i Materiały z Dziejów Nauki” 2012, no. 1-2, pp. 339-352.

Jarosz D., Pasztor M., Robineau, Bassaler i inni. Z dziejów stosunków polsko-francuskich w latach 1948-1953, Torun 2001.

Jarosz D., Pasztor M., Rola sporu o Bibliotekę Polska w Paryżu w stosunkach polsko-francuskich w latach 1945-1980, "Z Badań nad Książką i Księgozbiorami Historycznymi”, 2006, vol. 1, pp. 31-47.

Kisztelińska-Węgrzyńska A., Traktaty polsko-austriackie z lat 1955-1989. Wybór umów dwustronnych, Łódź 2011.

Pasztor M., Francuska polityka “budowania mostów” w dzielacej się Europie - przykład Polski i Czechosłowacji (1944-1947), "Studia z Dziejów Rosji i Europy Środkowo-Wschodniej” 2002, vol. 37, pp. 117-131.

Pasztor M., Jarosz D., Działalność Instytutu Francuskiego w Polsce w latach 1925-1989. Część druga: lata 1945-1989, "Polski Przegląd Dyplomatyczny” 2008, no. 3, pp. 119-146.

Pasztor M., Jarosz D., Nie tylko Fiat. Z dziejów stosunków polsko-włoskich 1945-1989, Warszawa 2018.

Syndoman S., Polsko-austriackie stosunki dyplomatyczne i kontakty polityczne $w$ latach 1970-1989, [in:] Austria i relacje polsko-austriackie w XX i XXI wieku. Polityka - kultura - gospodarka, ed. by A. Kisztelińska-Węgrzyńska and K.A. Kuczyński, Łódź 2014, pp. 103-116.

Tebinka J., Dyplomacja popaździernikowa,[in]: Historia dyplomacji polskiej. T. 6: 1944/1945-1989, ed. by W. Materski and W. Michowicz, Warszawa 2010. 